\title{
Immune Check Point Inhibitors in Primary Cutaneous T-Cell Lymphomas: Biologic Rationale, Clinical Results and Future Perspectives
}

OPEN ACCESS

Edited by: Nihal Ahmad,

University of Wisconsin-Madison, United States

Reviewed by: Stefan Schieke, University of Wisconsin-Madison, United States Andrei Chapoval, Altai State University, Russia

${ }^{*}$ Correspondence: Pietro Quaglino pietro.quaglino@unito.it

${ }^{\dagger}$ These authors have contributed equally to this work and share first authorship

Specialty section: This article was submitted to Skin Cancer,

a section of the journal Frontiers in Oncology

Received: 30 June 2021 Accepted: 30 July 2021 Published: 16 August 2021

Citation:

Roccuzzo G, Giordano S, Fava P, Pileri A, Guglielmo A, Tonella L, Sanlorenzo M, Ribero S, Fierro MT and Quaglino P (2021) Immune Check Point Inhibitors in

Primary Cutaneous T-Cell

Lymphomas: Biologic

Rationale, Clinical Results and Future Perspectives.

Front. Oncol. 11:733770. doi: 10.3389/fonc.2021.733770

\begin{abstract}
Gabriele Roccuzzo ${ }^{1 \dagger}$, Silvia Giordano ${ }^{1 \dagger}$, Paolo Fava ${ }^{1}$, Alessandro Pileri ${ }^{2,3}$, Alba Guglielmo ${ }^{2,3}$, Luca Tonella ${ }^{1}$, Martina Sanlorenzo ${ }^{4}$, Simone Ribero ${ }^{1}$, Maria Teresa Fierro ${ }^{1}$ and Pietro Quaglino ${ }^{1 *}$

${ }^{1}$ Department of Medical Sciences, Section of Dermatology, University of Turin, Turin, Italy, ${ }^{2}$ Dermatology-IRCCS Policlinico
di Sant'Orsola Department of Experimental, Diagnostic and Specialty Medicine, Alma Mater Studiorum, University of
Bologna, Bologna, Italy, ${ }^{3}$ Dermatology Unit, Department of Experimental, Diagnostic and Specialty Medicine, University of
Bologna, Bologna, Italy, ${ }^{4}$ Department of Medicine, Institute of Cancer Research, Medical University of Vienna, Vienna, Austria
\end{abstract}

Primary cutaneous T-cell lymphomas (PCTCL) are the most common types of cutaneous lymphomas, with Mycosis fungoides as the most frequent subtype. Besides early stages which usually have a good prognosis, advanced stages remain a great therapeutic challenge with low survival rates. To date, none of the currently available therapeutic options have significantly improved the outcomes of advanced cutaneous lymphomas. Recent studies have demonstrated that immune-checkpoint molecules, such as PD-1 and CTLA-4, play part in the proliferation pathways of neoplastic T-cells, as well as in other tumors. Hence, the potential role of immune-checkpoint-inhibitors in treating cutaneous lymphomas has been investigated in the last years. Herein, we outline the current knowledge regarding the role of immune-checkpoint molecules in PCTCL, their signaling pathways, microenvironment and therapeutic inhibition rationale. Moreover, we review the published data on immunotherapies in PCTCL and summarize the currently ongoing clinical trials in this field.

Keywords: Cutaneous T-cell lymphomas, immunotherapy, Mycosis fungoides, immune-checkpoint-inhibitors, Sézary syndrome, nivolumab, pembrolizumab

\section{INTRODUCTION}

Primary cutaneous lymphomas (PCL) are a family of rare non-Hodgkin's lymphomas (NHL) characterized by monoclonal proliferation of malignant lymphocytes in the skin. Among them, 75\% are represented by Cutaneous T-cell lymphoma (CTCL), with Mycosis Fungoides (MF) as the most common subtype, while $25 \%$ are Cutaneous B-Cell lymphoma (CBCL) (1). Rarer yet more aggressive, defined by the triad of T-cell leukemic evolution, lymphadenopathy and erythroderma, is the Sézary syndrome (SS) form, which can develop as a final manifestation of MF or appear de novo (2). Recently it has been suggested that due to their different T-cell subsets 
origin SS and MF may represent two distinct pathological entities (3). In the recent years, there has been a growing interest in the understanding of molecular and immunological mechanisms that play a role in tumor development and progression: for instance, it has been well documented that the host's immune system acts as an active player in modulating the defense response against tumor progression (4). These findings have led to an unprecedent development of new immune-based therapies in the oncology field (5). To date, the world of immuno-oncology, which comprehends all those treatments aimed at manipulating the host's immune system in order to stop tumor proliferation, has achieved remarkable results in several tumors, such as melanoma, lung, kidney, and bladder cancer (6-9). Interestingly, recent studies on the pathogenesis of CTCL have also identified potential immunological targets for therapeutic approaches aimed at enhancing cell-mediated immunity (10). In particular, the role of immune checkpoint antibodies against PD1 (Programmed cell death protein 1) has been subject of inquiry in the last few years, as it has been proved that by targeting inhibitory PD-1 molecules expressed by exhausted $\mathrm{T}$ cells, these drugs can revitalize antitumor $\mathrm{T}$ cells and lead to impressive clinical responses $(11,12)$. In this review of the literature, we outline the current evidence on the interactions between CTCL and the immune system, review the published data on immunotherapies for CTCL and summarize the noteworthy ongoing clinical trials in this field.

\section{PRIMARY CUTANEOUS T-CELL LYMPHOMAS: AN OVERVIEW}

The cluster of primary cutaneous T-cell lymphomas (PCTCL) encompasses several lymphomatous entities with common defining underlying features (13). Among them, MF is the most common subtype, representing around $55 \%$ of the cases, with an incidence rate of about 5.6 per million people and a stable trend in the last two decades (14). Regardless of the traditionally described histopathological variants (i.e., folliculotropic, pagetoid reticulosis, granulomatous slack skin), the current 2007 staging system is based on a tumor-node-metastasis-blood involvement (TNMB) classification and correlates the clinical features with the prognosis (15). Early stages (IA, IB, IIA), characterized by longstanding erythematous scaly patches/plaques, typically located in the bathing trunk areas, usually show an indolent course: even though the 5-year disease free survival is high (i.e., varying from $98 \%$ to $89 \%$ ), there is still considerable morbidity from pain, itching, discomfort, and disfigurement (16-20). Moreover, according to an Italian retrospective study on 1,422 MF patients, $29.7 \%$ of earlystage disease develops a disease progression (18). Advanced stages are conversely identified by skin tumors (stage IIB) or erythroderma (stage III), while blood (stage IVA1), nodal (stage IVA2) and visceral involvement (stage IVB) define the most severe extracutaneous forms $(16,19,21)$. Regardless of the clinical onset, MF patients can later develop systemic manifestations of SS (22). The survival rates dramatically drop in the most advanced stages, with 5 -year OS rates falling from $56 \%$ in IIB to $18 \%$ in IVB stages (16).
Along with the clinical features, other factors contribute to the biological evolution of the disease: for example, age over 60, largecell transformation and increased $\mathrm{LDH}$ values have been described as independent unfavorable variables (23). Still today prompt diagnosis remains a great challenge for clinicians, as almost 9 out of 10 cases show a significant time delay between symptoms onset and confirmed diagnosis (19).

\section{CURRENT THERAPIES FOR CTCL}

All the most recent published treatment guidelines agree on a stage-driven strategy, in consideration of clinical presentation, symptom burden and patient's comorbidities. However, due to the lack of strong evidence from clinical trials, there is currently no unanimous agreement on the sequence by which treatments should be administered: in fact, the choice of any specific therapy should primarily take into account several factors such as disease subtype, patient age/comorbidities, disease extension and treatment availabilities (24). The main goal of therapy is to improve the quality of life, by reducing symptoms, as durable complete remission is rarely achieved (24). With the exception of few selected stage IA patients, in which expectant policy and watchful waiting may be considered, treatment is recommended in all other cases. In early stages (IA, IB, IIA) first line options include skin direct therapies (SDT) such as topical corticosteroids, topical bexarotene, ultraviolet phototherapy, radiation therapy and the recently EMA-approved topical chlormethine (25). Those refractory to the first line may be considered for systemic therapies, such as retinoids, Interferon alpha, Total Skin Electron Beam therapy (TSEB) or low-dose methotrexate, which conversely represent first-line treatments for stage IIB MF $(25,26)$. Stage III patients may benefit from extracorporeal phototherapy (ECP), whilst refractory and stage IV patients have been traditionally treated with chemotherapy regimens (gemcitabine, pegylated liposomal doxorubicine, CHOP and CHOP-like polychemotherapy) (26). Patients with advanced MF or SS still have an unmet clinical need of effective treatments, due to low response rates, short-lived improvements, concomitant immunosuppression, and often severe drug-related side effects. Overall survival rates in SS are still low, varying from 7.5 to 22.4 months (27). Allogeneic stem cell transplantation (alloSCT), particularly using reduced-intensity conditioning, remains the only treatment option with curative intention for few selected patients (28). Notably, new options have become available in the last years. The anti-CD52 monoclonal antibody Alemtuzumab has shown significant clinical activity in patients with previously treated advanced MF/SS and constitutes a second-line option for patients with advanced disease, although with less efficacy in tumor-stage MF and large cell transformation types $(29,30)$. The ALCANZA trial led to the approval of the anti-CD30 monoclonal antibody Brentuximab Vedotin in patients with CD30+ MF, showing an ORR lasting at least 4 months of $56 \%$ compared to $13 \%$ in the control arm in which MTX or bexarotene were administered (31). Moreover, the MAVORIC trial compared the anti-CCR4 antibody 
Mogamulizumab with Vorinostat, showing a significantly higher ORR in the former arm (28\% vs 5\%) and resulting in mogamulizumab approval for patients with high Sezary cell burden (32). Among histone deacetylase inhibitors, Vorinostat and Romidopsin have been approved by FDA as second line therapies for CTCL patients, whilst they are currently not available in Europe $(33,34)$. To date, regardless of the encouraging results of some trials on the aforementioned drugs, there is still no curative therapy that has represented a major breakthrough in the outcomes of CTCL. Ultimately, the latest therapeutic frontier has been set in motion by new studies regarding the potential role of immune-checkpoint-inhibitors in CTCL. Fully understanding the tumor microenvironment and its relationship with the host's immune system is crucial to develop new effective and highly specific immunotherapies.

\section{THE ROLE OF TUMOR MICROENVIRONMENT IN PRIMARY CUTANEOUS LYMPHOMA}

Since the introduction of so-called immunoediting theory an increasing number of studies have focused on the interaction between the malignancy and the microenvironment: nonimmune cells (such as antigen-presenting cells), cells exerting immunosuppressive action or activated T-lymphocytes against neoplastic cells (35). All the studies have highlighted such interactions between the tumour and its microenvironment that are fundamental for MF/SS progression. Globally, in the advanced stages there is a switch from an anti-tumour (Th1) phenotype to a tumorigenic (Th2) one. In the early 2000s it was hypothesised that dendritic cells (DCs) may play an important role in CTCL progression (36-42). Indeed, an accumulation of immature DCs has been thought to be related to MF progression, owing to the immune-suppressive actions that immature DCs may play on activated T-cells, leading to anergy. Another debated category of cells are immune-suppressive cells such as T-reg cells or myeloid derived suppressor cells (MDSCs). In pioneering studies the former has been proposed as the normal counterpart of MF cells, evidence confuted later by the introduction of more specific immunohistochemistry antibody (43-50). Today, the role of Tregs seems to be related to a therapeutic response but it is still far to be fully understood (51-53). Studies on MDSCs are few and hypothesise a role in MF progression as well as the fact that MDSCs can be a marker of treatment response $(42,54,55)$. Another intriguing category of cells are tumour-infiltrating lymphocytes (TILs). TILs try to control malignant T-lymphocytes and the main problem is that currently no specific markers can be used to distinguish benign from malignant T-cells. In advanced stages it has been proposed that an accumulation of exhausted anti-tumour cells may be one of the events leading to immune-suppression in MF/SS (56). Furthermore, in contrast to the plasticity of malignant T-cells that can express different phenotypes, TILs may have a constrained one (57). Consequently, malignant T-cells may have the ability to elude the control of the immune system. Eosinophils, macrophages, and endothelial cells may play a role in MF/SS progression. In hematologic malignancies it has been proposed that macrophages may recruit eosinophils via the production of vascular endothelial growth factors (VEGFs) $(58,59)$. However, it's still unclear whether eosinophils may exert an anti-tumour or tumorigenic role (60). Eosinophils within MF/SS infiltrate are rare. Most of the studies on the role of eosinophils provide contrasting results. Indeed, some groups have observed a significantly higher number of eosinophils in the advanced stages, while other studies have not found correlations between the eosinophil level and the disease stage (61-65). Currently, most studies suggest that eosinophils may play a tumorigenic role in $\mathrm{MF} /$ SS or may not exert an anti-tumour action at all. The role of macrophages in CTCLs is clearly tumorigenic and mounting evidence has proven that a polarisation to M2 (CD163+) macrophages is related to disease progression. M2 macrophages have an immune suppressive role leading to $\mathrm{MF} / \mathrm{SS}$ progression. M2 macrophage accumulation starts in early MF phases and increases in the plaque and tumour stages (66-69). Some Authors have observed an accumulation of periostin-stimulated macrophages in plaque-stage MF that may lead to formation of the tumour lesions, while M2 macrophages may play an important role in maintaining an immunosuppressive tumour microenvironment later. Moreover, the interaction between neoplastic $\mathrm{T}$-cells and the microenvironment also involves keratinocytes, fibroblasts and endothelial cells. A loop has been hypothesised between neoplastic elements and keratinocytes as well as fibroblasts that may lead to a permanent activation of STAT proteins with the production of tumorigenic (Th2) molecules (70). STAT overexpression determines a feedback loop between keratinocytes, stromal, and malignant T-cells leading as a consequence to a Th2 polarization of the inflammatory milieu and an empowerment of STAT overexpression (71). Evidence that endothelial cells can play an important role in MF progression has been clearly observed. By comparing MF infiltrate with healthy donor skin different groups have been proven to have an increase in microvascular density in MF $(42,72-75)$. Moreover, markers of both neo-angiogenesis such as VEGFA or lymph-angiogenesis (VEGF-C) have been observed as overexpressed in MF/SS highlighting the concept that during MF progression both an increase in blood and in lymphatic vessels can be advantageous to tumour survival and spread $(42,73)$. In conclusion, in CTCL a switch from an anti-tumour to a tumorigenic phenotype can help the disease to survive and spread to the lymph-nodes and the internal organs. Indeed, the accumulation of exhausted anti-tumour $\mathrm{T}$ cells and the increase in immuno-suppressive cells may lead to a cascade of events including an empowerment of immunesuppressive cytokine release as well as an increase in neoangiogenesis which has the consequence of providing an advantage to the disease.

\section{THE PD-1/PDL-1 AXIS IN PRIMARY CUTANEOUS LYMPHOMA}

The immunological interactions between Programmed cell death receptor 1 (PD-1) and its ligands (PD-L1 and PD-L2) expressed 
on cell membranes have been well documented in the scientific literature, as engagement of PD-1 with PD-L1/PD-L2 has shown to prevent $\mathrm{T}$-cell activation and proliferation, weakening immune response (76). These findings have represented a breakthrough in the immuno-oncology field, leading to the understanding that tumor infiltrating $\mathrm{T}$-cells are often functionally impaired due to high expression of PD-1 levels, while malignant cells can escape immune surveillance by expressing PD-L1 (77). Similarly, overexpression of other inhibitory checkpoint receptors, such as the B7-ligand known as CTLA-4 (Cytotoxic T-Lymphocyte Antigen 4), has been proved to lessen immune surveillance in tumors (78). Hence, throughout the years, antibodies targeting PD-1 and CTLA-4 have been developed for treating several tumors, with the aim of restoring PD-1+ T-cell function and eventually halting tumor proliferation (79). In the growing field of immuno-oncology, studies have been carried out in order to achieve a thorough understanding of PD-1 and CTLA-4 expression in cutaneous lymphomas as well (80). The results have been diverse and noteworthy. Firstly, it has been shown that PD-1 and CTLA-4 are expressed by malignant cutaneous T-cells in MF and SS, while PD-L1 levels are high in dendritic cells émigrés from the skin but low in T-cells themselves $(56,81,82)$. The different proportion of PD-1 expressing T-cells in MF and SS groups, reported as $13 \%$ in the former and $89 \%$ in the latter, has provided further evidence for considering them as two distinct entities (83). Secondly, PD-1 expression can help differentiate SS patients, in which PD-1 is highly expressed on neoplastic CD4 + cells, from patients affected by other inflammatory dermatoses, in which PD-1 is more often expressed by CD8+ cells (84). Klemke et al. proved that loss of CD7 and increased PD-1 expression in $>50 \%$ of the lymphocytic infiltrates discriminates SS from other erythrodermic inflammatory dermatoses (85). Kantekure et al. have also suggested that PD-1 expression seems to increase with lymphoma progression, correlating with an enhanced immunosuppressive microenvironment (10). However, while the progressive nature of immunosuppression in CTCL is well recognized, the mechanisms that underlie the immune impairment remain essentially unknown (10). The major part seems to be played by the interaction between PD-1 and its ligands PD-L1/PD-L2, as it leads to the transduction of a signal which inhibits the T-cell function, attenuating the immune response and the antitumor activity (86). Besides CTCL, this increased PD-1 expression has been also reported in several other models of defective immune function, including chronic viral infections (87-90). Conversely, high number of tumor-infiltrating CD8+ $\mathrm{T}$ cells in MF lesions correlates with a more favorable outcome (91). Moreover, the understanding that CTCL cells, as well as other cancer cells, are capable of evading immune surveillance has been documented by detecting a reduced TH1response and an enhanced TH2-switch in MF lesions (92-94). All these aspects, along with the immunosuppression observed during disease progression and the evidence of common alterations in immune checkpoint related genes, have brought clinicians to theorize a therapeutic role of immune check point inhibitors in treating CTCL $(95,96)$. Herein we summarize the current available results, as far as anti-PD1 and anti-CTLA4 therapies for CTCL are concerned.

\section{RESULTS OF CLINICAL TRIALS}

To date only few studies related to safety and efficacy of ICI use in treating CTCL have been published. Two open-label trials have shown some significant results. The former is a phase I study conducted by Lesokhin et al. in which nivolumab, administered at dosage of 1 or $3 \mathrm{mg} / \mathrm{kg}$ every 3 weeks, showed a good tolerability profile in 81 patients with hematologic malignancies (97). Specifically, in the T-cell lymphoma subset, thirteen patients were affected by MF, five by PTCL (Peripheral T-cell lymphoma) and five by other T-cell lymphomas. The ORR was $15 \%$ in patients with MF and $40 \%$ in those with PTCLs. $73 \%$ (i.e., 17/23) of these patients experienced some kind of adverse events (AEs), most commonly mild fatigue, rash, and pruritus, while 5 patients experienced $\geq$ grade 3 reactions. The latter is a phase II study in which 24 patients with pre-treated MF $(n=9)$ and SS $(n=15)$ received Pembrolizumab $2 \mathrm{mg} / \mathrm{kg}$ every 3 weeks for up to 2 years (12). In this case, the ORR was 38\%, with two CRs (complete responses) and seven PRs (partial responses). The median response follow-up time was 58 weeks. Four patients discontinued treatment due to immune-related side effects, while $53 \%$ of the patients with SS experienced cutaneous flare reactions. This occurrence was found to be associated with high PD-1 expression on Sézary cells. Furthermore, interesting preliminary clinical data were obtained in a phase $1 \mathrm{~b}$ study in which 12 patients with relapsed/refractory PTCL and CTCL received pembrolizumab in combination with pralatrexate, a dihydrofolate reductase inhibitor, or decitabine, a cytidine analog, or both pralatrexate and decitabine (98). One patient achieved CR, two had PR, one stayed in SD (stable disease) and two experienced PD (progression disease). All responses were seen in the triple combination arm of pembrolizumab, pralatrexate and decitabine. This result suggests that the integration of pembrolizumab on an epigenetic backbone is safe and may improve the outlook in patients with PTCL and CTCL. Attention has also been focused on personalized treatments based on genomic features. A recent study by Beygi et al. hypothesized that genomic alterations of PD-L1, detected through Next Generation Sequencing techniques, may help predict response to $\mathrm{PD}-1$ targeting therapy in CTCLs: in fact, the identification of PD-L1 structural variants (SVs) as potential genomic biomarkers of response to PD-1 axis inhibition proved to be helpful in assessing the response to Pembrolizumab in 3 patients with CTCL (99). However, the authors acknowledged the need of further larger studies in order to fully explore the predictive value of PD-L1 alterations in CTLCs. As for CTLA-4 inhibiting antibodies, current data are even more limited, as its efficacy in CTCL has yet to be determined. To date, only two case reports have showed positive results. In a case report by Bar-Sela, a 44-year-old male with MF and melanoma, exhibited a complete resolution of MF cutaneous lesions after treatment with ipilimumab for advanced melanoma (100). In another case 
report, Sekulic et al. described the rapid response of a SS patient with a rare gene fusion between the extracellular/transmembrane domain of CTLA-4 (which has a high affinity for binding ligands) and the intracytoplasmic domain of PD-1 (101). Ultimately, combination of ipilimumab with nivolumab has been experienced in T-cell lymphomas. In a phase I study of eleven patients, the efficacy of the combination was not superior to nivolumab monotherapy with an ORR of $9 \%$ and only $1 \mathrm{PR}$ observed (102). Altogether, these findings regarding the role of PD-1 axis in CTCLs confirm the great need for further investigations in this field (103). Here we outline a synopsis of the currently published studies and the ongoing clinical trials (103, 104) (Tables 1, 2).

\section{DISCUSSION AND FUTURE PERSPECTIVES}

The role of immune checkpoint inhibitors in the treatment of CTCL still represents a unique challenge in immuno-oncology, as the exact role of PD-1 and its ligands in tumor microenvironment of patients with CTCL is not fully understood and may differ from other tumors (105-107). This peculiarity is related to the fact that the tumor itself arises from CD4+ T-cells, a population responsible for priming of the cytotoxic response; therefore, it has been speculated that targeting immune checkpoints would have implications on the functionality of both helper and cytotoxic T cells (108). Hence, as for the PD-1 axis, a substantial difference can be noted between solid tumors and CTCL: in the former group, neoplastic cells express PD-L1 which binds to PD-1 on Tcells, inhibiting their activity. Therefore, targeting PD-1 with anti-PD-1 antibodies can prevent this inhibitory interaction, restoring T-cell function. Conversely, the peculiarity of PD-1 expression in CTCL resides in the fact that the proliferating neoplastic itself is a CD4+ T-cell. In this specific case, targeting PD-1 with anti-PD-1 antibodies could have a double effect: on the one hand, this could restore the antineoplastic function of TILs as in solid tumors, while on the other, this could promote the proliferation of the neoplastic T-cell population $(109,110)$. Several questions have been raised and still need to be answered. O'Malley et al. showed that over $86 \%$ of malignant T-cells in patients with CTCL express PD-1, compared with $16 \%$ of benign $\mathrm{T}$ cells, suggesting that preferential expression of $\mathrm{PD}-1$ by malignant $\mathrm{T}$ cells may underlie worsening of clinical disease in a subset of patients treated with PD-1 blockade (111). Saulite et al. also emphasized that blocking PD-1 in SS reduces Th2 phenotype of non-neoplastic T-cell and may paradoxically enhance tumor proliferation (105). Similarly, Sivanand et al. brought attention to the controversy that, if expression of PD-1 on malignant Tcell has an inhibitory function, PD-1 blockade can potentially

TABLE 1 | Summary of the published results from the main studies on immunotherapy in CTCL.

\begin{tabular}{|c|c|c|c|c|c|c|}
\hline Target & Drug & Study Type & $\begin{array}{c}\mathrm{N}^{\circ} \\
\text { of } \\
\text { pts }\end{array}$ & Inclusion & ORR & Disease outcome \\
\hline $\begin{array}{l}\text { PD-1 } \\
\text { (Lesokhin) }\end{array}$ & Nivolumab & $\begin{array}{l}\text { Phase I open-label dose- } \\
\text { escalation, cohort- } \\
\text { expansion basket }\end{array}$ & 13 & Heavily pretreated MF & $15 \%$ & $\begin{array}{l}\text { Duration of response up } \\
\text { to } 81 \text { weeks }\end{array}$ \\
\hline $\begin{array}{l}\text { PD-1 } \\
\text { (Khodadoust) }\end{array}$ & Pembrolizumab & Phase II & 24 & $\begin{array}{l}\text { MF/SS patients ( } 23 \text { of } 24 \\
\text { with stage IIB to IV) and } \\
\text { heavily pretreated }\end{array}$ & $38 \%$ & $\begin{array}{l}8 \text { durable responses } \\
\text { (median DOR not } \\
\text { reached }>58 \text { weeks) }\end{array}$ \\
\hline $\begin{array}{l}\text { PD-1 } \\
\text { (Marchi) }\end{array}$ & $\begin{array}{l}\text { Pembrolizumab in } \\
\text { combination with } \\
\text { epigenetic drugs }\end{array}$ & $\begin{array}{l}\text { Phase } 1 \mathrm{~b} \\
\text { Three arms (4 patients } \\
\text { per arm): } \\
\text { A: pembrolizumab + } \\
\text { pralatrexate } \\
\text { B: pembrolizumab + } \\
\text { pralatrexate + decitabine } \\
\text { C: pembrolizumab + } \\
\text { decitabine }\end{array}$ & 12 & $\begin{array}{l}\text { Relapsed/refractory TCL (5 } \\
\mathrm{PCTL}, 3 \mathrm{AITL} \text {, } 1 \text { ATLL } \\
2 \mathrm{MF} \text { and } 1 \mathrm{SS} \text { ). } \\
\text { *Angioimmunoblastic T-cell } \\
\text { lymphoma } \\
{ }^{\circ} \text { Adult-T-cell lymphoma/ } \\
\text { leukemia }\end{array}$ & $\begin{array}{l}6 \text { out of } 12 \text { patients evaluable } \\
\text { for response at the time of } \\
\text { analysis }\end{array}$ & Arm B: 2/4 (CR, PR) \\
\hline PD-1 (Beygi) & Pembrolizumab & $\begin{array}{l}\text { Case report on } 3 \text { patients } \\
\text { Pt.1 Pembrolizumab + IFNg } \\
6 \text { cycles, Pembrolizumab } \\
\text { alone } 36 \text { cycles; } \\
\text { Pt.2 Pembrolizumab } 2 \\
\text { cycles } \\
\text { Pt.3 Pembrolizumab } 6 \\
\text { cycles }\end{array}$ & 3 & $\begin{array}{l}\text { Pt.1 Stage IIB MF } \\
\text { Pt.2 Stage IVB MF } \\
\text { Pt.3 Stage IIB MF }\end{array}$ & $\begin{array}{l}\text { Duration of response: } \\
\text { Pt.1 } 12 \text { weeks (first round), } 110 \\
\text { weeks (second round in } \\
\text { combination with RT) } \\
\text { Pt.2 } 12 \text { weeks } \\
\text { Pt.3 } 9 \text { weeks }\end{array}$ & $\begin{array}{l}\text { Pt.1 SD } \\
\text { Pt.2 Discontinuation due } \\
\text { to immune-related } \\
\text { pneumonitis } \\
\text { Pt.3 PD }\end{array}$ \\
\hline $\begin{array}{l}\text { CTLA-4 } \\
\text { (Bar-Sela) }\end{array}$ & Ipililumab & Case report & 1 & Stage IA MF & $\mathrm{CR}$ & - \\
\hline $\begin{array}{l}\text { CTLA-4 } \\
\text { (Sekulic) }\end{array}$ & Ipililumab & Case report & 1 & Stage IVA SS & PR 6 weeks & $\begin{array}{l}\text { Death } 3 \text { months after } \\
\text { last dose }\end{array}$ \\
\hline
\end{tabular}

ORR, Overall response rate; Pt, patient; Arm A, Arm B, Arm C. 
TABLE 2 | Summary of the currently ongoing trials on immunotherapy in CTCL.

\begin{tabular}{|c|c|c|c|c|c|c|}
\hline Study & $\begin{array}{l}\text { Type } \\
\text { of } \\
\text { study }\end{array}$ & Drug & Inclusion criteria & $\begin{array}{l}\text { Start } \\
\text { date }\end{array}$ & $\begin{array}{l}\text { Primary } \\
\text { completion }\end{array}$ & $\begin{array}{l}\text { Study } \\
\text { completion }\end{array}$ \\
\hline NCT03063632 & $\begin{array}{l}\text { Phase } \\
\text { ॥ }\end{array}$ & Pembrolizumab + Interferon-gamma & $\begin{array}{l}\text { Relapsed-Non respondent (stage IB-IVB) MF, SS and } \\
\text { Advanced Synovial Sarcoma }\end{array}$ & $\begin{array}{c}\text { Oct } 13 \text {, } \\
2017\end{array}$ & Apr 8, 2021 & Apr 8, 2022 \\
\hline NCT03278782 & $\begin{array}{l}\text { Phase } \\
|/ /|\end{array}$ & Pembrolizumab + Romidepsin & $\begin{array}{l}\text { Relapsed-refractory- non respondent peripheral T-cell } \\
\text { Lymphoma }\end{array}$ & $\begin{array}{l}\text { Nov } \\
14 \\
2017\end{array}$ & $\begin{array}{l}\text { Nov } 30 \\
2021\end{array}$ & $\begin{array}{l}\text { Nov } 30 \\
2021\end{array}$ \\
\hline NCT02581631 & $\begin{array}{l}\text { Phase } \\
\text { I/II }\end{array}$ & Nivolumab + Brentuximab Vedotin & Relapsed-refractory- non respondent NHL CD30+ & $\begin{array}{l}\text { Dec } \\
18 \\
2015\end{array}$ & $\begin{array}{c}\text { Jan } 16 \\
2020\end{array}$ & $\begin{array}{l}\text { Aug } 30 \\
2021\end{array}$ \\
\hline NCT02978625 & $\begin{array}{l}\text { Phase } \\
\text { ॥ }\end{array}$ & $\begin{array}{l}\text { Talimogene Laherparepvec followed by } \\
\text { Talimogene Laherparepvec + Nivolumab }\end{array}$ & $\begin{array}{l}\text { Refractory T-cell and NK Cell Lymphomas, Cutaneous } \\
\text { SCC, Merkel Cell Carcinoma, and Other Rare Skin Tumors. }\end{array}$ & $\begin{array}{l}\text { Sept } \\
18 \\
2017\end{array}$ & $\begin{array}{l}\text { June 1, } \\
2022\end{array}$ & $\begin{array}{c}\text { June 1, } \\
2022\end{array}$ \\
\hline NCT03011814 & $\begin{array}{l}\text { Phase } \\
\text { I/II }\end{array}$ & $\begin{array}{l}\text { Durvalumab as a single agent or with } \\
\text { Lenalidomide }\end{array}$ & Relapsed/refractory PTCL including CTCL & $\begin{array}{l}\text { March } \\
8 \\
2017\end{array}$ & $\begin{array}{l}\text { June 8, } \\
2022\end{array}$ & $\begin{array}{l}\text { June 8, } \\
2022\end{array}$ \\
\hline NCT03357224 & $\begin{array}{l}\text { Phase } \\
\text { ॥ }\end{array}$ & Atezolizumab & Relapsed or refractory stage IIb-IV MF-SS & $\begin{array}{l}\text { Sept } \\
24 \\
2018\end{array}$ & Sept, 2021 & June, 2025 \\
\hline
\end{tabular}

promote tumor growth (110). Another topic of discussion is the heterogeneity of results as far as PD-1 expression on T-cell in MF and SS is concerned: in fact, while some authors have reported an augmented expression in a substantial proportion of both MF and SS patients, others have described it as more relevant in SS only $(111,112)$. Moreover, recent studies about neoantigen heterogeneity have emphasized the role of mutational load in CTCL: Iyer et al. have proved that as MF progresses, the tumor accumulates somatic mutations and evolves to produce multiple genetic subclones (113). Sivanand et al. suggested that this process has a double effect, as on one hand it leads to higher neoantigen expression and increased opportunities for the neoplasm to be recognized by the immune system, while on the other the increasing subclonal distribution of neoantigens can direct the immune system to discrete subpopulations of the most immunogenic tumor cells (114). This in turn may shield the less immunogenic subclones from the antitumor attack and limit efficacy of immunotherapy in $\operatorname{MF}(114,115)$. As for the other main actor in the ICI class (i.e., CTLA-4), even less evidence has been found so far: in fact, while Querfeld et al. observed a promising higher expression of CTLA-4 in CTCL, Anzengruber et al. reported no significant differences with healthy controls $(116,117)$. To date, as the combination of anti-PD-1+anti-CTLA-4 showed no benefit over anti-PD1 alone, there are no current active trials on the efficacy of CTLA-4 in CTCL (118). All evidence considered, it remains challenging to come to a univocal conclusion on the efficacy of ICI in CTCL. New interesting data may come from other less characterized, yet worthy of mention, ICI molecules: for example, FRCL3 (Fc receptor-like 3), TIGIT (T-cell immunoreceptor with Ig and ITIM domains), BTLA (B and T Lymphocyte Associated), ICOS (Inducible T-cell costimulator) and LAG-3 (Lymphocyteactivation gene 3 ) have been found to be significantly upregulated in CTCL and this finding could represent a new frontier in the research of new target therapies $(108,117,119,120)$. Recently, new findings regarding ICOS expression in CTCL cells seem to provide the preliminary basis for therapeutic trials, as anti-ICOS antibodydrug conjugates proved antitumor potential against CTCL cell lines and patient-derived xenografts (121). Nevertheless, no in vivo studies testing the blockage of these molecules have been started so far. Finally, it is worth mentioning that few authors have listed T-cell lymphomas among the potential, yet very rare, immunerelated adverse events following ICIs use: for instance, in the 20122018 FAERS (Food and Drug Administration Adverse Events Reporting System) pharmacovigilance database a $0.02 \%$ incidence of T-cell lymphoma post-ICIs use, with a $17 \%$ mortality, was registered (122). It has been speculated that this phenomenon might be associated with rebound overexpression of PD-1 after the treatment, however actual mechanisms remain still unknown and further studies are needed to better characterize this paradoxical occurrence $(123,124)$. In conclusion, this literature review highlights the potential role of immune-check point inhibitors in CTCL, according to the current available data. Altogether, the outlook of using ICI in this field seems to be less favorable compared to the one observed in other tumors, such as melanoma (6). Carrying out new research, aimed at disentangling the complex relationship between CTCL and the host's immune system, may hopefully lead to a more detailed understanding of immunological targetable molecules, in order to provide patients with innovative therapeutic chances.

\section{AUTHOR CONTRIBUTIONS}

PQ, MF, SR, and PF conceived and designed the presented review. GR, SG, AP, and AG wrote the manuscript with input from all authors. MS and LT analyzed the data. PQ, MF, SR, PF, GR, SG, AP, AG, MS, and LT contributed to the implementation of the research. All authors contributed to the article and approved the submitted version. 


\section{REFERENCES}

1. Willemze R, Jaffe ES, Burg G, Cerroni L, Berti E, Swerdlow SH, et al. WHOEORTC Classification for Cutaneous Lymphomas. Blood (2005) 105:376885. doi: 10.1182/blood-2004-09-3502

2. Swerdlow SH, Campo E, Pileri SA, Harris NL, Stein H, Siebert R, et al. The 2016 Revision of the World Health Organization Classification of Lymphoid Neoplasms. Blood (2016) 127:2375-90. doi: 10.1182/blood-2016-01-643569

3. Campbell JJ, Clark RA, Watanabe R, Kupper TS. Sezary Syndrome and Mycosis Fungoides Arise From Distinct T-Cell Subsets: A Biologic Rationale for Their Distinct Clinical Behaviors. Blood (2010) 116(5):767-71. doi: 10.1182/blood-2009-11-251926

4. Burnet FM. The Concept of Immunological Surveillance. Prog Exp Tumor Res (1970) 13:1-27. doi: 10.1159/000386035

5. Duan J, Cui L, Zhao X, Bai H, Cai S, Wang G, et al. Use of Immunotherapy With Programmed Cell Death 1 vs Programmed Cell Death Ligand 1 Inhibitors in Patients With Cancer: A Systematic Review and Meta-Analysis. JAMA Oncol (2020) 6(3):375-84. doi: 10.1001/jamaoncol.2019.5367

6. Lo JA, Fisher DE. The Melanoma Revolution: From UV Carcinogenesis to a New Era in Therapeutics. Science (2014) 346(6212):945-9. doi: 10.1126/ science. 1253735

7. Ellis PM, Vella ET, Ung YC. Immune Checkpoint Inhibitors for Patients With Advanced Non-Small-Cell Lung Cancer: A Systematic Review. Clin Lung Cancer (2017) 18(5):444-59.e1. doi: 10.1016/j.cllc.2017.02.001

8. Fahmy O, Khairul-Asri MG, Stenzl A, Gakis G. The Current Status of Checkpoint Inhibitors in Metastatic Bladder Cancer. Clin Exp Metastasis (2016) 33(7):629-35. doi: 10.1007/s10585-016-9807-9

9. Wallis CJD, Klaassen Z, Bhindi B, Ye XY, Chandrasekar T, Farrell AM, et al. First-Line Systemic Therapy for Metastatic Renal Cell Carcinoma: A Systematic Review and Network Meta-Analysis. Eur Urol (2018) 74 (3):309-21. doi: 10.1016/j.eururo.2018.03.036

10. Kantekure K, Yang Y, Raghunath P, Schaffer A, Woetmann A, Zhang Q, et al. Expression Patterns of the Immunosuppressive Proteins PD-1/CD279 and PD-L1/ CD274 at Different Stages of Cutaneous T-Cell Lymphoma/Mycosis Fungoides. Am J Dermatopathol (2012) 34:126-8. doi: 10.1097/DAD.0b013e31821c35cb

11. Shalabi D, Bistline A, Alpdogan O, Kartan S, Mishra A, Porcu P, et al. Immune Evasion and Current Immunotherapy Strategies in Mycosis Fungoides (MF) and Sézary Syndrome (Ss). Chin Clin Oncol (2019) 8 (1):11. doi: $10.21037 /$ cco.2019.01.01

12. Khodadoust MS, Rook AH, Porcu P, Foss F, Moskowitz AJ, Shustov A, et al. Pembrolizumab in Relapsed and Refractory Mycosis Fungoides and Sézary Syndrome: A Multicenter Phase II Study. J Clin Oncol (2020) 38(1):20-8. doi: 10.1200/JCO.19.01056

13. Intro Willemze R, Jaffe ES, Burg G, Cerroni L, Berti E, Swerdlow SH, et al. WHO-EORTC Classification for Cutaneous Lymphomas. Blood (2005) 105:3768-85. doi: 10.1182/blood-2004-09-3502

14. Korgavkar K, Xiong M, Weinstock M. Changing Incidence Trends of Cutaneous T-Cell Lymphoma. JAMA Dermatol (2013) 149(11):1295-9. doi: 10.1001/jamadermatol.2013.5526

15. Olsen E, Vonderheid E, Pimpinelli N, Willemze R, Kim Y, Knobler R, et al. Revisions to the Staging and Classification of Mycosis Fungoides and Sezary Syndrome: A Proposal of the International Society for Cutaneous Lymphomas (ISCL) and the Cutaneous Lymphoma Task Force of the European Organization of Research and Treatment of Cancer (EORTC). Blood (2007) 110(6):1713-22. doi: 10.1182/blood-2007-03-055749

16. Agar NS, Wedgeworth E, Crichton S, Mitchell TJ, Cox M, Ferreira S, et al. Survival Outcomes and Prognostic Factors in Mycosis Fungoides/Sezary Syndrome: Validation of the Revised International Society of Cutaneous Lymphomas/European Organisation for Research and Treatment of Cancer Staging Proposal. J Clin Oncol (2010) 28:4730-9. doi: 10.1200/JCO.2009.27.7665

17. Talpur R, Singh L, Daulat S, Liu P, Seyfer S, Trynosky T, et al. Long-Term Outcomes of 1263 Patients With Mycosis Fungoides and Sézary Syndrome From 1982 to 2009. Clin Cancer Res (2012) 18:5051-60. doi: 10.1158/10780432.CCR-12-0604

18. Quaglino P, Pimpinelli N, Berti E, Calzavara-Pinton P, Alfonso Lombardo G, Rupoli S, et al. Time Course, Clinical Pathways, and Long-Term Hazards Risk Trends of Disease Progression in Patients With Classic Mycosis Fungoides: A Multicenter, Retrospective Follow-Up Study From the
Italian Group of Cutaneous Lymphomas. Cancer (2012) 118:5830-9. doi $10.1002 /$ cncr.27627

19. Scarisbrick JJ, Quaglino P, Prince HM, Papadavid E, Hodak E, Bagot M, et al. The PROCLIPI International Registry of Early-Stage Mycosis Fungoides Identifies Substantial Diagnostic Delay in Most Patients. Br J Dermatol (2018) 181:350-7. doi: 10.1111/bjd.17258

20. Quaglino P, Maule M, Prince HM, Porcu P, Horwitz S, Duvic M, et al. Global Patterns of Care in Advanced Stage Mycosis Fungoides/Sezary Syndrome: A Multicenter Retrospective Follow-Up Study From the Cutaneous Lymphoma International Consortium. Ann Oncol (2017) 28(10):2517-25. doi: 10.1093/annonc/mdx352

21. Scarisbrick JJ, Kim YH, Whittaker SJ, Wood GS, Vermeer MH, Prince HM, et al. Prognostic Factors, Prognostic Indices and Staging in Mycosis Fungoides and Sézary Syndrome: Where Are We Now. Br J Dermatol (2014) Jun170(6):1226-36. doi: 10.1111/bjd.12909

22. Kim YH, Liu HL, Mraz-Gernhard S, Varghese A, Hoppe RT, et al. LongTerm Outcome of 525 Patients With Mycosis Fungoides and Sezary Syndrome: Clinical Prognostic Factors and Risk for Disease Progression. Arch Dermatol (2003) 139:857-66. doi: 10.1001/archderm.139.7.857

23. Scarisbrick JJ, Prince HM, Vermeer MH, Quaglino P, Horwitz S, Porcu P, et al. Cutaneous Lymphoma International Consortium Study of Outcome in Advanced Stages of Mycosis Fungoides and Sézary Syndrome: Effect of Specific Prognostic Markers on Survival and Development of a Prognostic Model. J Clin Oncol (2015) 33(32):3766-73 doi: 10.1200/JCO.2015.61.7142.

24. Trautinger F, Eder J, Assaf C, Bagot M, Cozzio A, Dummer R, et al. European Organisation for Research and Treatment of Cancer Consensus Recommendations for the Treatment of Mycosis Fungoides/Sézary Syndrome - Update 2017. Eur J Cancer (2017) 77:57-74. doi: 10.1016/j.ejca.2017.02.027

25. Willemze R, Hodak E, Zinzani PL, Specht L, Ladetto M. ESMO Guidelines Committee. Primary Cutaneous Lymphomas: ESMO Clinical Practice Guidelines for Diagnosis, Treatment and Follow-Up. Ann Oncol (2018) 29:iv30-40. doi: 10.1093/annonc/mdy133

26. Mehta-Shah N, Horwitz SM, Ansell S, Ai WZ, Barnes J, Barta SK, et al. NCCN Guidelines Insights: Primary Cutaneous Lymphomas, Version 2.2020. J Nat Compr Canc Netw (2020) 18(5):522-36. doi: 10.6004/jnccn.2020.0022

27. Janiga J, Kentley J, Nabhan C, Abdulla F. Current Systemic Therapeutic Options for Advanced Mycosis Fungoides and Sézary Syndrome. Leuk Lymphoma (2018) 59(3):562-77. doi: 10.1080/10428194.2017.1347650

28. Wang Y, Bagot M. Updates in Cutaneous Lymphoma: Evidence-Based Guidelines for the Management of Cutaneous Lymphoma 2018. Br J Dermatol (2019) 180:443-4. doi: 10.1111/bjd.17523

29. Kennedy GA, Seymour JF, Wolf M, Januszewicz H, Davison J, McCormack C, et al. Treatment of Patients With Advanced Mycosis Fungoides and Sé Zary Syndrome With Alemtuzumab. Eur J Haematol (2003) 71:250-6. doi: 10.1034/j.1600-0609.2003.00143.x

30. de Masson A, Guitera P, Brice P, Moulonguet I, Mouly F, Bouaziz JD, et al. LongTerm Efficacy and Safety of Alemtuzumab in Advanced Primary Cutaneous TCell Lym- Phomas. Br J Dermatol (2014) 170:720-4. doi: 10.1111/bjd.12690

31. Prince HM, Kim YH, Horwitz SM, Dummer R, Scarisbrick J, Quaglino P, et al. Brentuximab Vedotin or Physician's Choice in CD30-Positive Cutaneous T-Cell Lymphoma (ALCANZA): An International, OpenLabel, Randomised, Phase 3, Multicentre Trial. Lancet (2017) 390:555-66. doi: 10.1016/S0140-6736(17)31266-7

32. Kim YH, Bagot M, Pinter-Brown L, Rook AH, Porcu P, Horwitz SM, et al. Mogamulizumab Versus Vorinostat in Previously Treated Cutaneous T-Cell Lymphoma (MAVORIC): An International, Open-Label, Randomised, Controlled Phase 3 Trial. Lancet Oncol (2018) 19:1192-204. doi: 10.1016/S1470-2045(18)30379-6

33. Duvic M, Talpur R, Ni X, Zhang C, Hazarika P, Kelly C, et al. Phase 2 Trial of Oral Vorinostat (Suberoylanilide Hydroxamic Acid, SAHA) for Refractory Cutaneous T-Cell Lymphoma (CTCL). Blood (2007) 109:31-9. doi: 10.1182/ blood-2006-06-025999

34. Whittaker SJ, Demierre M-F, Kim EJ, Rook AH, Lerner A, Duvic M, et al. Final Results From a Multicenter, International, Pivotal Study of Romidepsin in Refractory Cutaneous T-Cell Lym- Phoma. J Clin Oncol (2010) 28(29):4485e91. doi: 10.1200/JCO.2010.28.9066

35. Dunn GP, Old LJ, Schreiber RD. The Immunobiology of Cancer Immunosurveillance and Immunoediting. Immunity (2004) 21(2):137-48. doi: 10.1016/j.immuni.2004.07.017 
36. Pimpinelli N, Santucci M, Romagnoli P, Giannotti B. Dendritic Cells in Tand B-Cell Proliferation in the Skin. Dermatol Clin (1994) 12(2):255-70. doi: 10.1016/S0733-8635(18)30173-6

37. Nestle FO, Nickoloff BJ. Role of Dendritic Cells in Benign and Malignant Lymphocytic Infiltrates of the Skin. Dermatol Clin (1994) 12(2):271-82. doi: 10.1016/S0733-8635(18)30174-8

38. Lüftl M, Feng A, Licha E, Schuler G. Dendritic Cells and Apoptosis in Mycosis Fungoides. Br J Dermatol (2002) 147(6):1171-9. doi: 10.1046/ j.1365-2133.2002.04994.x

39. Schlapbach C, Ochsenbein A, Kaelin U, Hassan AS, Hunger RE, Yawalkar N. High Numbers of DC-SIGN+ Dendritic Cells in Lesional Skin of Cutaneous T-Cell Lymphoma. J Am Acad Dermatol (2010) 62(6):995-1004. doi: 10.1016/j.jaad.2009.06.082

40. Schwingshackl P, Obermoser G, Nguyen VA, Fritsch P, Sepp N, Romani N. Distribution and Maturation of Skin Dendritic Cell Subsets in Two Forms of Cutaneous T-Cell Lymphoma: Mycosis Fungoides and Sézary Syndrome. Acta Derm Venereol (2012) 92(3):269-75. doi: 10.2340/00015555-1220

41. Zhang QA, Chen ZQ, Chen MH, Xu ZD. The Number of Regular T Cells and Immature Dendritic Cells Involved in Mycosis Fungoides Is Linked to the Tumor Stage. Eur Rev Med Pharmacol Sci (2014) 18(4):553-8.

42. Pileri A, Agostinelli C, Righi S, Fuligni F, Bacci F, Sabattini E, et al. Vascular Endothelial Growth Factor A (VEGFA) Expression in Mycosis Fungoides. Histopathology (2015) 66(2):173-81. doi: 10.1111/his.12445

43. Klemke CD, Fritzsching B, Franz B, Kleinmann EV, Oberle N, Poenitz N, et al. Paucity of FOXP3+ Cells in Skin and Peripheral Blood Distinguishes Sézary Syndrome From Other Cutaneous T-Cell Lymphomas. Leukemia (2006) 20(6):1123-9. doi: 10.1038/sj.leu.2404182

44. Tiemessen MM, Mitchell TJ, Hendry L, Whittaker SJ, Taams LS, John S. Lack of Suppressive CD4+CD25+FOXP3 + T Cells in Advanced Stages of Primary Cutaneous T-Cell Lymphoma. J Invest Dermatol (2006) 126 (10):2217-23. doi: 10.1038/sj.jid.5700371

45. Gjerdrum LM, Woetmann A, Odum N, Burton CM, Rossen K, Skovgaard GL, et al. FOXP3+ Regulatory T Cells in Cutaneous T-Cell Lymphomas: Association With Disease Stage and Survival. Leukemia (2007) 21(12):25128. doi: $10.1038 /$ sj.leu. 2404913

46. Capriotti E, Vonderheid EC, Thoburn CJ, Wasik MA, Bahler DW, Hess AD. Expression of T-Plastin, FoxP3 and Other Tumor-Associated Markers by Leukemic T-Cells of Cutaneous T-Cell Lymphoma. Leuk Lymphoma (2008) 49(6):1190-201. doi: 10.1080/10428190802064917

47. Solomon GJ, Magro CM. Foxp3 Expression in Cutaneous T-Cell Lymphocytic Infiltrates. J Cutan Pathol (2008) 35(11):1032-9. doi: 10.1111/j.16000560.2007.00969.x

48. Wada DA, Wilcox RA, Weenig RH, Gibson LE. Paucity of Intraepidermal FoxP3-Positive T Cells in Cutaneous T-Cell Lymphoma in Contrast With Spongiotic and Lichenoid Dermatitis. J Cutan Pathol (2010) 37(5):535-41. doi: $10.1111 /$ j.1600-0560.2009.01381.x

49. Alcántara-Hernández M, Torres-Zárate C, Pérez-Montesinos G, JuradoSantacruz F, Domínguez-Gómez MA, Peniche-Castellanos A, et al. Overexpression of Hypoxia-Inducible Factor 1 Alpha Impacts FoxP3 Levels in Mycosis Fungoides-Cutaneous T-Cell Lymphoma: Clinical Implications. Int J Cancer (2014) 134(9):2136-45. doi: 10.1002/ijc.28546

50. Shareef MM, Elgarhy LH, Wasfy R-S. Expression of Granulysin and FOXP3 in Cutaneous T Cell Lymphoma and Sézary Syndrome. Asian Pac J Cancer Prev (2015) 16(13):5359-64. doi: 10.7314/apjcp.2015.16.13.5359

51. Querfeld C, Rosen ST, Guitart J, Duvic M, Kim YH, Dusza SW, et al. Results of an Open-Label Multicenter Phase 2 Trial of Lenalidomide Monotherapy in Refractory Mycosis Fungoides and Sézary Syndrome. Blood (2014) 123 (8):1159-66. doi: 10.1182/blood-2013-09-525915

52. Ni X, Jorgensen JL, Goswami M, Challagundla P, Decker WK, Kim YH, et al. Reduction of Regulatory T Cells by Mogamulizumab, a Defucosylated AntiCC Chemokine Receptor 4 Antibody, in Patients With Aggressive/ Refractory Mycosis Fungoides and Sézary Syndrome. Clin Cancer Res (2015) 21(2):274-85. doi: 10.1158/1078-0432.CCR-14-0830

53. Shiue LH, Couturier J, Lewis DE, Wei C, Ni X, Duvic M. The Effect of Extracorporeal Photopheresis Alone or in Combination Therapy on Circulating CD4(+) Foxp3(+) CD25(-) T Cells in Patients With Leukemic Cutaneous T-Cell Lymphoma. Photodermatol Photoimmunol Photomed (2015) 31(4):184-94. doi: 10.1111/phpp.12175
54. Geskin LJ, Akilov OE, Kwon S, Schowalter M, Watkins S, Whiteside TL, et al. Therapeutic Reduction of Cell-Mediated Immunosuppression in Mycosis Fungoides and Sézary Syndrome. Cancer Immunol Immunother (2018) 67(3):423-34. doi: 10.1007/s00262-017-2090-z

55. Argyropoulos KV, Pulitzer M, Perez S, Korkolopoulou P, Angelopoulou M, Baxevanis C, et al. Tumor-Infiltrating and Circulating Granulocytic Myeloid-Derived Suppressor Cells Correlate With Disease Activity and Adverse Clinical Outcomes in Mycosis Fungoides. Clin Transl Oncol (2020) 22:1059-66. doi: 10.1007/s12094-019-02231-7

56. Querfeld C, Leung S, Myskowski PL, Curran SA, Goldman DA, Heller G, et al. Primary T Cells From Cutaneous T-Cell Lymphoma Skin Explants Display an Exhausted Immune Checkpoint Profile. Cancer Immunol Res (2018) 6:900-9. doi: 10.1158/2326-6066.CIR-17-0270

57. Murray D, McMurray JL, Eldershaw S, Pearce H, Davies N, Scarisbrick JJ, et al. Progression of Mycosis Fungoides Occurs Through Divergence of Tumor Immunophenotype by Differential Expression of HLA-Dr. Blood $A d v$ (2019) 3(4):519-30. doi: 10.1182/bloodadvances.2018025114

58. Granata F, Frattini A, Loffredo S, Staiano RI, Petraroli A, Ribatti D, et al. Production of Vascular Endothelial Growth Factors From Human Lung Macrophages Induced by Group IIA and Group X Secreted Phospholipases A2. J Immunol (2010) 184(9):5232-41. doi: 10.4049/jimmunol.0902501

59. Detoraki A, Staiano RI, Granata F, Giannattasio G, Prevete N, de Paulis A, et al. Vascular Endothelial Growth Factors Synthesized by Human Lung Mast Cells Exert Angiogenic Effects. J Allergy Clin Immunol (2009) 123 (5):1142-9, 1149.e1-5. doi: 10.1016/j.jaci.2009.01.044

60. Simon SCS, Utikal J, Umansky V. Opposing Roles of Eosinophils in Cancer. Cancer Immunol Immunother (2019) 68(5):823-33. doi: 10.1007/s00262018-2255-4

61. Iliadis A, Koletsa T, Patsatsi A, Georgiou E, Sotiriadis D, Kostopoulos I. The Cellular Microenvironment and Neoplastic Population in Mycosis Fungoides Skin Lesions: A Clinicopathological Correlation. Eur J Dermatol (2016) 26(6):566-71. doi: 10.1684/ejd.2016.2847

62. Bahalı AG, Su O, Cengiz FP, Emiroğlu N, Ozkaya DB, Onsun N. Prognostic Factors of Patients With Mycosis Fungoides. Postepy Dermatol Alergol (2020) 37(5):796-9. doi: 10.5114/ada.2020.100491

63. Kural YB, Su O, Onsun N, Uras AR. Atopy, IgE and Eosinophilic Cationic Protein Concentration, Specific IgE Positivity, Eosinophil Count in Cutaneous T Cell Lymphoma. Int J Dermatol (2010) 49(4):390-5. doi: $10.1111 / j .1365-4632.2010 .04228 . x$

64. Tancrède-Bohin E, Ionescu MA, de la Salmonière P, Dupuy A, Rivet J, Rybojad M, et al. Prognostic Value of Blood Eosinophilia in Primary Cutaneous T-Cell Lymphomas. Arch Dermatol (2004) 140(9):1057-61. doi: 10.1001 /archderm.140.9.1057

65. Ionescu MA, Rivet J, Daneshpouy M, Briere J, Morel P, Janin A. In Situ Eosinophil Activation in 26 Primary Cutaneous T-Cell Lymphomas With Blood Eosinophilia. J Am Acad Dermatol (2005) 52(1):32-9. doi: 10.1016/ j.jaad.2004.03.003

66. Tada K, Hamada T, Asagoe K, Umemura H, Mizuno-Ikeda K, Aoyama Y, et al. Increase of DC-LAMP+ Mature Dendritic Cell Subsets in Dermatopathic Lymphadenitis of Mycosis Fungoides. Eur J Dermatol (2014) 24(6):670-5. doi: 10.1684/ejd.2014.2437

67. Furudate S, Fujimura T, Kakizaki A, Kambayashi Y, Asano M, Watabe A, et al. The Possible Interaction Between Periostin Expressed by Cancer Stroma and Tumor-Associated Macrophages in Developing Mycosis Fungoides. Exp Dermatol (2016) 25(2):107-12. doi: 10.1111/exd.12873

68. Ando T, Xiao W, Gao P, Namiranian S, Matsumoto K, Tomimori Y, et al. Critical Role for Mast Cell Stat5 Activity in Skin Inflammation. Cell Rep (2014) 6(2):366-76. doi: 10.1016/j.celrep.2013.12.029

69. Zhou W, Ke SQ, Huang Z, Flavahan W, Fang X, Paul J, et al. Periostin Secreted by Glioblastoma Stem Cells Recruits M2 Tumour-Associated Macrophages and Promotes Malignant Growth. Nat Cell Biol (2015) 17 (2):170-82. doi: 10.1038/ncb3090

70. Nestle FO, Di Meglio P, Qin JZ, Nickoloff BJ. Skin Immune Sentinels in Health and Disease. Nat Rev Immunol (2009) 9(10):679-91. doi: 10.1038/nri2622

71. Takahashi N, Sugaya M, Suga H, Oka T, Kawaguchi M, Miyagaki T, et al. Thymic Stromal Chemokine TSLP Acts Through Th2 Cytokine Production to Induce Cutaneous T-Cell Lymphoma. Cancer Res (2016) 76(21):6241-52. doi: 10.1158/0008-5472.CAN-16-0992 
72. Krejsgaard T, Vetter-Kauczok CS, Woetmann A, Lovato P, Labuda T, Eriksen KW, et al. Jak3- and JNK-Dependent Vascular Endothelial Growth Factor Expression in Cutaneous T-Cell Lymphoma. Leukemia (2006) 20(10):1759-66. doi: 10.1038/sj.leu.2404350

73. Vacca A, Moretti S, Ribatti D, Pellegrino A, Pimpinelli N, Bianchi B, et al. Progression of Mycosis Fungoides Is Associated With Changes in Angiogenesis and Expression of the Matrix Metalloproteinases 2 and 9. Eur J Cancer (1997) 33(10):1685-92. doi: 10.1016/s0959-8049(97)00186-x

74. Karpova MB, Fujii K, Jenni D, Dummer R, Urosevic-Maiwald M. Evaluation of Lymphangiogenic Markers in Sézary Syndrome. Leuk Lymphoma (2011) 52(3):491-501. doi: 10.3109/10428194.2010.517877

75. Pedersen IH, Willerslev-Olsen A, Vetter-Kauczok C, Krejsgaard T, Lauenborg B, Kopp KL, et al. Vascular Endothelial Growth Factor Receptor-3 Expression in Mycosis Fungoides. Leuk Lymphoma (2013) 54 (4):819-26. doi: 10.3109/10428194.2012.726720

76. Jin HT, Ahmed R, Okazaki T. Role of PD-1 in Regulating T-Cell Immunity. Curr Top Microbiol Immunol (2011) 350:17-37. doi: 10.1007/82_2010_116

77. Zou W, Wolchok JD, Chen L. PD-L1 (B7-H1) and PD-1 Pathway Blockade for Cancer Therapy: Mechanisms, Response Biomarkers, and Combinations. Sci Transl Med (2016) 8:328rv4. doi: 10.1126/scitranslmed.aad7118

78. Schietinger A, Greenberg PD. Tolerance and Exhaustion: Defining Mechanisms of T Cell Dysfunction. Trends Immunol (2014) 35(2):51-60. doi: 10.1016/j.it.2013.10.001

79. Topalian SL, Drake CG, Pardoll DM. Immune Checkpoint Blockade: A Common Denominator Approach to Cancer Therapy. Cancer Cell (2015) 27:450-61. doi: 10.1016/j.ccell.2015.03.001

80. Quaglino P, Fava P, Pileri A, Grandi V, Sanlorenzo M, Panasiti V, et al. Phenotypical Markers, Molecular Mutations, and Immune Microenvironment as Targets for New Treatments in Patients With Mycosis Fungoides and/or Sézary Syndrome. J Invest Dermatol (2021) 141(3):484-95. doi: 10.1016/ j.jid.2020.07.026

81. Wada DA, Wilcox RA, Harrington SM, Kwon ED, Ansell SM, Comfere NI. Programmed Death 1 is Expressed in Cutaneous Infiltrates of Mycosis Fungoides and Sezary Syndrome. AmJ Hematol (2011) 86:325-7. doi: 10.1002/ajh.21960

82. Saulite I, Ignatova D, Chang YT, Fassnacht C, Dimitriou F, Varypataki E, et al. Blockade of Programmed Cell Death Protein 1 (PD-1) in Śzary Syndrome Reduces Th2 Phenotype of Non-Tumoral T Lymphocytes But may Enhance Tumor Proliferation. Oncoimmunology (2020) 9(1):1738797. doi: $10.1080 / 2162402 X .2020 .1738797$

83. Cetinözman F, Jansen PM, Vermeer MH, Willemze R. Differential Expression of Programmed Death-1 (PD-1) in Sézary Syndrome and Mycosis Fungoides. Arch Dermatol (2012) 148:1379-85. doi: 10.1001/ archdermatol.2012.2089

84. Çetinözman F, Jansen PM, Willemze R. Expression of Programmed Death-1 in Skin Biopsies of Benign Inflammatory vs. Lymphomatous Erythroderma. Br J Dermatol (2014) 171:499-504. doi: 10.1111/bjd.12934

85. Klemke CD, Booken N, Weiss C, Nicolay JP, Goerdt S, Felcht M, et al. Histopathological and Immunophenotypical Criteria for the Diagnosis of Sézary Syndrome in Differentiation From Other Erythrodermic Skin Diseases: A European Organisation for Research and Treatment of Cancer (EORTC) Cutaneous Lymphoma Task Force Study of 97 Cases. $\mathrm{Br} J$ Dermatol (2015) 173(1):93-105. doi: 10.1111/bjd.13832

86. Samimi S, Benoit B, Evans K, Wherry EJ, Showe L, Wysocka M, et al. Increased Programmed Death-1 Expression on CD 4 T Cells in Cutaneous T-Cell Lym-phoma: Implications for Immune Suppression. Arch Dermatol (2010) 146:1382-8. doi: 10.1001/archdermatol.2010.200

87. Trautmann L, Janbazian L, Chomont N, Said EA, Gimmig S, Bessette B, et al. Upregulation of PD-1 Expression on HIV-Specific CD8 T Cells Leads to Reversible Immune Dysfunction. Nat Med (2006) 12(10):1198-202. doi: $10.1038 / \mathrm{nm} 1482$

88. Day CL, Kaufmann DE, Kiepiela P, Brown JA, Moodley ES, Reddy S, et al. PD-1 Expression on HIV-Specific Tcells Is Associated With T-Cell Exhaustion and Disease Progression. Nature (2006) 443(7109):350-4. doi: 10.1038/nature05115

89. Urbani S, Amadei B, Tola D, Massari M, Schivazappa S, Missale G, et al. PD-1 Expression in Acute Hepatitis C Virus (HCV) Infection Is Associated With HCV-Specific CD8 Exhaustion. J Virol (2006) 80(22):11398-403. doi: 10.1128/JVI.01177-06
90. Shimauchi T, Kabashima K, Nakashima D, Sugita K, Yamada Y, Hino R, et al. Augmented Expression of Programmed Death-1 in Both Neoplastic and non-Neoplastic CD4 T-Cells in Adult T-Cell Leukemia/Lymphoma. Int J Cancer (2007) 121(12):2585-90. doi: 10.1002/ijc.23042

91. Hoppe RT, Medeiros LJ, Warnke RA, Wood GS. CD8-Positive TumorInfiltrating Lymphocytes Influence the Long-Term Survival of Patients With Mycosis Fungoides. J Am Acad Dermatol (1995) 32:448-53. doi: 10.1016/ 0190-9622(95)90067-5

92. Chong BF, Wilson AJ, Gibson HM, Hafner MS, Luo Y, Hedgcock CJ, et al. Immune Function Abnormalities in Peripheral Blood Mononuclear Cell Cytokine Expression Differentiates Stages of Cutaneous T-Cell Lymphoma/ Mycosis Fungoides. Clin Cancer Res (2008) 14:646-53. doi: 10.1158/10780432.CCR-07-0610

93. Vowels BR, Lessin SR, Cassin M, Jaworsky C, Benoit B, Wolfe JT, et al. Th2 Cytokine mRNA Expression in Skin in Cutaneous T-Cell Lymphoma. J Invest Dermatol (1994) 103:669-73. doi: 10.1111/1523-1747.ep12398454

94. Lessin SR, Vowels BR, Rook AH. Th2 Cytokine Profile in Cutaneous T-Cell Lymphoma. J Invest Dermatol (1995) 105:855-6. doi: 10.1111/15231747.ep12326693

95. Krejsgaard T, Odum N, Geisler C, Wasik MA Woetmann A. Regulatory T Cells and Immunodeficiency in Mycosis Fungoides and Sézary Syndrome. Leukemia (2012) 26:424-32. doi: 10.1038/leu.2011.237

96. Ungewickell A, Bhaduri A, Rios E, Reuter J, Lee CS, Mah A, et al. Genomic Analysis of Mycosis Fungoides and Sézary Syndrome Identifies Recurrent Alterations in TNFR2. Nat Genet (2015) 47:1056-60. doi: 10.1038/ng.3370

97. Lesokhin AM, Ansell SM, Armand P, Scott EC, Halwani A, Gutierrez M, et al. Nivolumab in Patients With Relapsed or Refractory Hematologic Malignancy: Preliminary Results of a Phase Ib Study. J Clin Oncol (2016) 34 (23):2698-704. doi: 10.1200/JCO.2015.65.9789

98. Marchi E, Ma H, Montanari F, Sawas A, Lue JK, Deng C, et al. The Integration of PD1 Blockade With Epigenetic Therapy is Highly Active and Safe in Heavily Treated Patients With T-Cell Lymphoma (PTCL) and Cutaneous T-Cell Lymphoma (CTCL). J Clin Oncol (2020) 38 (15_suppl):8049-9. doi: 10.1200/JCO.2020.38.15_suppl.8049

99. Beygi S, Fernandez-Pol S, Duran G, Wang EB, Stehr H, Zehnder JL, et al. Pembrolizumab in Mycosis Fungoides With PD-L1 Structural Variants. Blood Adv (2021) 5(3):771-4. doi: 10.1182/bloodadvances.2020002371

100. Bar-Sela G, Bergman R. Complete Regression of Mycosis Fungoides After Ipilimumab Therapy for Advanced Melanoma. JAAD Case Rep (2015) 1:99100. doi: 10.1016/j.jdcr.2015.02.009

101. Sekulic A, Liang WS, Tembe W, Izatt T, Kruglyak S, Kiefer JA, et al. Personalized Treatment of Sézary Syndrome by Targeting a Novel CTLA4: CD28 Fusion. Mol Genet Genomic Med (2015) 3(2):130-6. doi: 10.1002/ mgg3.121

102. Ansell S, Gutierrez ME, Shipp MA, Gladstone D, Moskowitz A, Borello I et al. A Phase 1 Study of Nivolumab in Combination With Ipilimumab for Relapsed or Refractory Hematologic Malignancies (CheckMate 039). Blood (2016) 128(22):183. doi: 10.1182/blood.V128.22.183.183

103. Dai J, Almazan T, Kim Y, Khodadoust M. Pembrolizumab in Systemic and Cutaneous T-Cell Lymphoma. Ann Lymphoma (2018) 2(4). doi: 10.21037/ aol.2018.03.02

104. Clinicaltrials.gov. National Institutes of Health, U.S. National Library of Medicine. Clinicaltrials.gov, Recruiting Studies - Cutaneous T Cell Lymphoma. (2021).

105. Saulite I, Ignatova D, Chang YT, Fassnacht C, Dimitriou F, Varypataki E, et al. Blockade of Programmed Cell Death Protein 1 (PD-1) in Sézary Syndrome Reduces Th2 Phenotype of Non-Tumoral T Lymphocytes But may Enhance Tumor Proliferation. Oncoimmunology (2020) 9(1):1738797. doi: 10.1080/2162402X.2020.1738797

106. Rubio Gonzalez B, Zain J, Rosen ST, Querfeld C. Tumor Microenvironment in Mycosis Fungoides and Sezary Syndrome. Curr Opin Oncol (2016) 28 (1):88-96. doi: 10.1097/CCO.0000000000000243

107. Armand P. Immune Checkpoint Blockade in Hematologic Malignancies. Blood (2015) 125(22):3393-400. doi: 10.1182/blood-2015-02-567453

108. Bobrowicz M, Fassnacht C, Ignatova D, Chang YT, Dimitriou F, Guenova E. Pathogenesis and Therapy of Primary Cutaneous T-Cell Lymphoma: Collegium Internationale Allergologicum (CIA) Update 2020. Int Arch Allergy Immunol (2020) 181(10):733-45. doi: 10.1159/000509281 
109. Wartewig T, Kurgyis Z, Keppler S, Pechloff K, Hameister E, Öllinger R, et al. PD-1 Is a Haploinsufficient Suppressor of T Cell Lymphomagenesis. Nature (2017) 552:121-5. doi: 10.1038/nature24649

110. Sivanand A, Surmanowicz P, Alhusayen R, Hull P, Litvinov IV, Zhou Y, et al. Immunotherapy for Cutaneous T-Cell Lymphoma: Current Landscape and Future Developments. J Cutan Med Surg (2019) 23(5):537-44. doi: 10.1177/ 1203475419867610

111. O’Malley JT, Gehad A, Lowry E, Teague J, LeBoeuf N, Kupper T, et al. 314 Preferential Expression of PD-1 on Malignant T Cells of CTCL May Underlie Disease Worsening in Patients Undergoing Anti-PD1 Therapy. J Invest Dermatol (2017) 137(5 suppl 1):S53. doi: 10.1016/j.jid.2017.02.330

112. Wada DA, Wilcox RA, Harrington SM, Kwon ED, Ansell SM, Comfere NI. Programmed Death 1 Is Expressed in Cutaneous Infiltrates of Mycosis Fungoi- Des and Śzary Syndrome. Am J Hematol (2011) 86:325-7. doi: 10.1002/ajh.21960

113. Iyer A, Hennessey D, O’Keefe S, Patterson J, Wang W, Wong GK, et al. Branched Evolution and Genomic Intratumor Heterogeneity in the Pathogenesis of Cutaneous T-Cell Lymphoma. Blood Adv (2020) 4 (11):2489-500. doi: 10.1182/bloodadvances.2020001441

114. Sivanand A, Hennessey D, Iyer A, O'Keefe S, Surmanowicz P, Vaid G, et al. The Neoantigen Landscape of Mycosis Fungoides. Front Immunol (2020) 11:561234. doi: 10.3389/fimmu.2020.561234

115. Milo I, Bedora-Faure M, Garcia Z, Thibaut R, Périé L, Shakhar G, et al. The Immune System Profoundly Restricts Intratumor Genetic Heterogeneity. Sci Immunol (2018) 3:eaat1435. doi: 10.1126/sciimmunol.aat1435

116. Querfeld C, Leung S, Myskowski PL, Curran SA, Goldman DA, Heller G, et al. Primary T Cells From Cutaneous T-Cell Lymphoma Skin Explants Display an Exhausted Immune Checkpoint Profile. Cancer Immunol Res (2018) 6:900-9. doi: 10.1158/2326-6066.CIR-17-0270

117. Anzengruber F, Ignatova D, Schlaepfer T, Chang YT, French LE, Pascolo S, et al. Divergent LAG-3 Versus BTLA, TIGIT, and FCRL3 Expression in Sézary Syndrome. Leuk Lymphoma (2019) 60(8):1899-907. doi: 10.1080/ 10428194.2018.1564827

118. Ansell S, Gutierrez ME, Shipp MA, Glad-stone D, Moskowitz A, Borello I, et al. A Phase 1 Study of Nivolumab in Combination With Ipilimumab for Relapsed or Refractory Hematologic Malignancies (CheckMate 039). Blood (2016) 128(22):183. doi: 10.1182/blood.V128.22.183.183

119. Spodzieja M, Lach S, Iwaszkiewicz J, Cesson V, Kalejta K, Olive D, et al. Design of Short Peptides to Block BTLA/HVEM Interactions for Promoting
Anticancer T-Cell Responses. PLoS ONE (2017) 12(6):e0179201. doi: 10.1371/journal.pone.0179201

120. Jariwala N, Benoit B, Kossenkov AV, Oetjen LK, Whelan TM, Cornejo CM, et al. TIGIT and Helios Are Highly Expressed on CD4+ T Cells in Śzary Syndrome Patients. J Invest Dermatol (2017) 137(1):257-60. doi: 10.1016/ j.jid.2016.08.016

121. Amatore F, Ortonne N, Lopez M, Orlanducci F, Castellano R, Ingen-HouszOro S, et al. ICOS is Widely Expressed in Cutaneous T-Cell Lymphoma, and Its Targeting Promotes Potent Killing of Malignant Cells. Blood Adv (2020) 4 (20):5203-14. doi: 10.1182/bloodadvances.2020002395

122. Anand K, Ensor J, Pingali SR, Hwu P, Duvic M, Chiang S, et al. T-Cell Lymphoma Secondary to Checkpoint Inhibitor Therapy. I Immunother Cancer (2020) 8(1):e000104. doi: 10.1136/jitc-2019-000104

123. Shin J, Ho Lee D, WJ L, Park CS. Mycosis Fungoides Development After Combined Immune Checkpoint Blockade Therapy in a Patient With Malignant Melanoma: A Case Report. Melanoma Res (2020) 30(5):515-8. doi: 10.1097/CMR.0000000000000664

124. Marks JA, Parker DC, Garrot LC, Lechowicz MJ. Nivolumab-Associated Cutaneous T-Cell Lymphoma. JAAD Case Rep (2021) 9:39-41. doi: 10.1016/ j.jdcr.2020.12.033

Conflict of Interest: The authors declare that the research was conducted in the absence of any commercial or financial relationships that could be construed as a potential conflict of interest.

Publisher's Note: All claims expressed in this article are solely those of the authors and do not necessarily represent those of their affiliated organizations, or those of the publisher, the editors and the reviewers. Any product that may be evaluated in this article, or claim that may be made by its manufacturer, is not guaranteed or endorsed by the publisher.

Copyright (๑) 2021 Roccuzzo, Giordano, Fava, Pileri, Guglielmo, Tonella, Sanlorenzo, Ribero, Fierro and Quaglino. This is an open-access article distributed under the terms of the Creative Commons Attribution License (CC BY). The use, distribution or reproduction in other forums is permitted, provided the original author(s) and the copyright owner(s) are credited and that the original publication in this journal is cited, in accordance with accepted academic practice. No use, distribution or reproduction is permitted which does not comply with these terms. 